\title{
Ignorerade band. Politik och ofullständiga ontologier i forskning om Sverigedemokraterna
}

\author{
Benjamin R. Teitelbaum
}

SAMMANDRAG: I sin artikel ifrågasätter Benjamin R. Teitelbaum det rådande paradigmet inom forskningen om Sverigedemokraterna. Han hävdar att politiska agendor leder akademiska och journalistiska kommentatorer till att använda en begränsande definition av partiet i sina analyser. Medan Sverigedemokraterna utgör en komplex politisk, ideologisk, social och kulturell rörelse så behandlas partimedlemmarna ofta av forskare enbart som politiska och ideologiska aktörer. Teitelbaum förtydligar sin ståndpunkt genom att granska ett återkommande tema i forskningen om partiet, nämligen huruvida Sverigedemokraterna kan kopplas till rasideologiska och högerextrema krafter i det svenska samhället. Han visar att medan de ideologiska sambanden mellan partiet och andra radikala nationalistiska krafter är svaga, så är de sociokulturella sambanden starka. Teitelbaum hävdar slutligen att dessa kopplingar förbises på grund av att de är mindre relevanta för dem som vill utmana partiet politiskt. Artikeln uppmanar till ett paradigmskifte inom forskningen, där Sverigedemokraterna börjar studeras som det mångfacetterade fenomen partiet är.

NYCKELORD: högerpopulism; extremism; etnografi; Sverigedemokraterna; forskningsetik; politisk kultur.

PUBLICERINGSHISTORIK: Originalpublicering.

BENJAMIN R. TEITELBAUM är lektor och prefekt i nordiska studier vid University of Colorado, Boulder.

E-POSTADRESS: benjamin.teitelbaum@colorado.edu

FÖRSLAG PÅ KÄLLANGIVELSE:

Teitelbaum, Benjamin R. (20I6) "Ignorerade band. Politik och ofullständiga ontologier i forskning om Sverigedemokraterna", i Det vita fältet III. Samtida forskning om högerextremism, specialnummer av Arkiv. Tidskrift för sambällsanalys, nr 5, s. 93-IIO. DOI: http://dx.doi.org/IO.I3068/2000-6217.5.4

(C) Benjamin R. Teitelbaum/Arkiv förlag \& tidskrift 2016 (publicerad I8 april 20I6)

Artikeln distribueras enligt en upphovsrättslicens från Creative Commons:

Erkännande-Ickekommersiell-IngaBearbetningar 3.0 Unported, som medger fri ickekommersiell användning och spridning i oförändrat skick så länge källan anges. 
Arkiv. Tidskrift för samhällsanalys är en sakkunniggranskad vetenskaplig tidskrift för samhällsvetenskap och historia. Samtliga artiklar publiceras fritt tillgängliga på:

$$
\text { www.tidskriftenarkiv.se }
$$

(beständig länk, DoI: http://dx.doi.org/IO.I3068/2000-62I7)

Den här artikeln finns tillgänglig i följande format:

PDF \& HTML: via beständig länk, DoI: http://dx.doi.org/IO.I3068/2000-62I7.5.4 EPUB: ingår i e-boksutgåva av numret, ISBN: 978 9I 79242763

TRYCK: ingår i bokutgåva av numret, ISBN: 978 9I 7924277 O

Grafisk utformning och sidnumrering är identisk i pdf och tryck.

Samtliga artiklar i nr 5 (20I6), Det vita fältet III. Samtida forskning om högerextremism, nås via beständig länk, Dor: http://dx.doi.org/I0.13068/2000-6217.5

Redaktion för numret: Mats Deland, Paul Fuehrer, Fredrik Hertzberg och Thomas Hvitfeldt

Arkiv. Tidskrift för samhällsanalys ISSN: 2000-62I7 (för elektronisk resurs) ISSN: 2000-6225 (för tryckta nummer)

ges ut av

Stiftelsen Arkiv för främjande och spridning av samhällsvetenskaplig och historisk forskning

genom

Arkiv förlag \& tidskrift

Box 1559 SE-22I OI Lund вESÖк: L Gråbrödersg 3 c, ipg TEL: 046-I3 3920

ARKIV FÖRLAG: arkiv@arkiv.nu·www.arkiv.nu TIDSKRIFTEN ARKIV: red@tidskriftenarkiv.se · www.tidskriftenarkiv.se

ANSVARIg UTGIVARE \& CHEFREDAKTÖR: Sven Hort AdMinistrativ Redaktör: David Lindberg Redaktörer: Paavo Bergman, Lisa Kings, Zhanna Kravchenko 


\title{
Ignorerade band. Politik och ofullständiga ontologier i forskning om Sverigedemokraterna
}

\author{
BENJAMIN R. TEITELBAUM
}

\author{
Minns du den tid som jag själv aldrig sett, \\ då folket var lyckligt, då folket var ett? \\ Så säg mig nu, pappa, hur känns det i dag, \\ när du sitter i slagget av det som finns kvar? \\ När du växte upp, säg mig hur var det då, \\ var en flicka någonting som man fritt gav sig på? \\ Gick du på gatan och lyssnade smått, \\ utan att höra ett ord du förstått? \\ Var du nånsin tvungen att ensam gå hem \\ sen du rånats och slagits av främmande män?
}

Låten ”Frågor till far” kom ut 2002 på singer-songwriter-skivan Frihetssånger, som i sin tur var den första av tre i ett skivprojekt kallat Svensk ungdom. Svensk ungdom var inte en musikgrupp - varje skiva hade en ny uppsättning musiker eller textförfattare. Men skivan Frihetssånger i allmänhet, och låten "Frågor till far" i synnerhet, skulle bli projektets största succé.

Skivorna producerades av det Sverigebaserade Nordiska förlaget som under 2000-talets första decennium var en av Nordens mest aktiva producenter och återförsäljare av radikal nationalistisk musik och litteratur (Wåg 20IO). Dess ledning bestod av aktivister från den rasideologiska tidningen Framtiden, vitmaktmusikmagasinet Nordland, samt den numera militanta nationalsocialistiska Svenska motståndsrörelsen. Med Nordiska 
förlaget hoppades ledningen på att kunna förändra motståndet till invandringen i Norden, främst genom att ge saken och dess företrädare en mer uppklädd och välordnad profil än den som rådde under 1990-talets nynazistiska skinnskallevåg. Trots det lyste förlagsledarnas bakgrund fram genom litteraturen de sålde och musiken de producerade.

Svensk ungdoms-skivan Frihetssånger innehåller låttexter av den kända svenske Hitlersympatisören Sven Olov Lindholm och i nyskrivna låtar som "Sverige har fallit" framträder antisemitiska inslag. "Frågor till far" däremot är tämligen moderat i sin kritik. Under låtens gång får lyssnaren möta en ung svensk som förhör sin far om hans likgiltighet inför en påstådd förstörelse av det svenska samhället under 1900-talets andra hälft. Frågorna målar upp en bild där icke-svenskar och förespråkare för mångkulturalism framstår som skurkar och en ny generation av svenskar står inför möjligheten att återskapa det som en gång var. Låttextens ospecificerade referenser - där "främlingar" och "folket" beskrivs i generella termer - gjorde att dess budskap lätt kunde anammas av en nordisk nationalism vars mångfald vid denna tid ökade vad gäller ideologi och metodik. Trots det blev "Frågor till far" aldrig en hit bland allmänheten. På grund av Nordiska förlagets bakgrund och polariserande ideologi begränsades spridningen till dem som redan var sammankopplade med den radikala högerns yttersta periferi och dess slutna kulturella nätverk.

Det är därför anmärkningsvärt att stora delar av Sverigedemokraternas aktivistkår och ledning känner till låten - många kan den utantill. Enligt partiets officiella ideologi borde det inte vara så. Nordiska förlaget ingick i den grupp av "etnonationalistiska" (det som forskarkåren kallar "rasideologiska") krafter, tillsammans med organisationer som Nordiska förbundet, Nationaldemokraterna, Nationalsocialistisk front och bulletinen Info-I4, som reformerade, färgblinda, "kulturnationalistiska" sverigedemokrater säger sig inte ha någonting med att göra. ${ }^{\mathrm{I}}$

Under de sex år som jag har följt Sverigedemokraterna som etnolog har jag träffat på låten överallt - i intervjuer, under informella samtal,

I. När en dold inspelning från Sveriges Radio visade att företrädare från Sverigedemokraternas ungdomsförbund hade sjungit andra låtar av Svensk ungdom under en privat fest räknades det internt som en pinsam skandal. Reportaget sändes i programmet Kaliber den 5 april 2009. Inspelningen finns tillgänglig via http://sverigesradio.se/sida/ artikel. aspx?programid=83\&artikel $=2747308$ (hämtat 29 januari 20I6). 
och på privata tillställningar. Chefsideologen Mattias Karlsson nämnde den medan vi diskuterade tillfällen då folk i partiet har kopplats samman med vitmaktmusik (intervju med Mattias Karlsson den 9 april 20I2):

KARLSSON: Eftersom det övriga samhället i en väldigt liten utsträckning sjunger om teman som skulle tilltala nationalister - historia, tradition, solidaritet, och så vidare - så kan jag säkert tänka mig att vissa kulturnationalister har lyssnat på enstaka låtar som man inte uppfattar som de mest radikala, där man sjunger om stolthet över landet eller någon del av vår historia. Då tänker man, ”jag gillar inte bandet, men den här låten är faktiskt ganska bra." [...] Har du hört den här "Frågor till far"? Den är väldigt uppskattad. Det är inget uttalat nazistiskt budskap, och musiken är inte heller det här hårda, skrikiga.

Teitelbaum: Ja, ja. Vad tycker du om den - du har hört den, va?

KARLSSON: Jag kände igen - hade jag hört den när jag var sexton hade jag nog tyckt att den var sjukt bra, för den beskriver ganska mycket känslan man hade när man var i den åldern.

Mattias Karlssons resonemang - som liknar det jag ofta hör från hans kollegor - är okomplicerat: låten i sig strider inte emot partiets ickerasistiska linje, och därför behöver inte sverigedemokrater som gillar den känna någon skuld. Men han tvekade smått när jag frågade honom om hans egen relation till "Frågor till far". Han ville inte erkänna att han tyckte om låten, utan sa att han skulle ha tyckt om den under andra omständigheter, och hans defensiva hållning - hans vägran att koppla ihop sig själv med låten - talar för en medvetenhet om kvarliggande problem. Eftersom Nordiska förlaget och dess produktioner cirkulerar i en marginaliserad, etnonationalistisk subkultur som partiet vill distansera sig från, kan man fråga sig hur Mattias Karlsson och hans partikamrater alls kommit i kontakt med låten.

Anledningen till att jag som etnolog har fokuserat på människors musikvanor är inte att jag vill lära mig om just sånger och melodier. Musiken fungerar som ett fönster, en inblick i individens, gruppens, eller kulturens världsåskådning och sociala position. Den visar - om än ofta genom krokiga och svårtolkade vägar - hur sociala aktörer relaterar till sin omgivning och hur de hanterar utmaningar.

Fallet med Sverigedemokraterna och "Frågor till far" introducerar oss till problematiken bakom en av de mest centrala frågorna i studier av 
partiet i dag: frågan om Sverigedemokraternas relation till den övriga radikalnationalistiska världen. Frågan har varit aktuell bland forskare i två decennier, alltsedan partiets kampanjer under mitten av 90-talet för att avkoppla sig från den övriga nationella rörelsen gav upphov till en våg av exposé-liknande studier och reportage som belyste brister i partiets påstådda distansering från "extremism". Vi ser nu en växande schism bland akademiska och journalistiska kommentatorer som behandlar frågan, med röster som Henrik Arnstad (2013) som menar att det inte finns någon väsentlig skillnad mellan $\mathrm{SD}$ och öppet fascistiska och nationalsocialistiska krafter från mellankrigstiden och framåt, och andra som Anna-Lena Lodenius (20I5), som hävdar att partiet har gjort upp med sitt extremistiska förflutna och numera klart hör till en närliggande men ändå distinkt politisk familj, den så kallade högerpopulistiska.

En liknande schism skulle förmodligen uppstå bland forskare som granskar "Frågor till far" och dess popularitet bland Sverigedemokraternas medlemmar. För vissa skulle partimedlemmars kunskap om och intresse för nästan okända etnonationalistiska band vara ett exempel på hur deras offentliga profil döljer en ideologisk koppling till en mer extrem politik - att dessa företrädare genom smak och tycke visar var de egentligen hör hemma på den ideologiska kartan. Å andra sidan skulle forskare med större tillit till partiets egen historieskrivning och självuppfattning tolka fallet "Frågor till far" som en relik från partiets tidigare engagemang i 1990-talets nationella rörelse, men inte som ett tecken på djupare ideologiska sympatier.

Mattias Karlssons egen förklaring lutar åt en mer nyanserad hållning. Låtens popularitet i vida nationalistiska kretsar handlar enligt honom om ideologiska likheter, men också om en gemensam social identitet rotad i ungdomen och ett utanförskap från Sveriges "mainstreamkultur”. Det är en förklaring som kräver vår uppmärksamhet, om än bara för att den utmanar oss till att vidga definitionen av Sverigedemokraterna och tänka på dess företrädare som mer än bara inkarnationer av politik och ideologi.

I denna artikel utforskar jag Sverigedemokraternas ideologiska relationer i förhållande till andra, mer radikala nationalistiska krafter i Sverige. Visst ser jag ett egenvärde i diskussionen då jag, liksom Mattias 
Karlsson, hävdar att det sociokulturella kan vara en betydande faktor i partiets fortsatta association med den övriga nationella rörelsen. Dock är mitt syfte mer omfattande än så. Genom att föra den här diskussionen vill jag rikta kritik mot tidigare studier av Sverigedemokraterna. Mitt budskap är att vi som forskare måste våga prata om partiet som mer än ett politiskt fenomen. Jag säger "våga", eftersom vi, om vi vill bredda fokus bortom Sverigedemokraternas ståndpunkter, policyer, och idéhistoria kommer att behöva släppa på ett outtalat mål inom en stor del av vårt arbete, nämligen att motverka partiets politiska framsteg. För att bättre kunna förstå Sverigedemokraterna som den dynamiska och mångsidiga rörelse partiet är måste vi skrota det rådande paradigm där det som räknas som intressant angående partiet främst är det som kan leda till dess underminering.

En artikel vars avsikt delvis är att granska ett akademiskt fält måste introduceras med en kommentar om författaren. Jag är själv aktiv forskare inom ämnet och givetvis betraktar jag andras studier utifrån en egen agenda. Som amerikansk akademiker utbildad inom humaniora och etnografi har jag en annan bakgrund än många som skriver om SD i dag, och dessa professionella och disciplinära omständigheter ligger till grund för min tolkning av forskningsfältet. Jag har en stark preferens för studier baserade på personlig kontakt och dialog med insiders. I mina egna verk om radikal nationalism i Norden (t.ex. Teitelbaum 20I3, 20I4, 2016 och [kommande]) har jag öppet förespråkat både utförlig etnografi och en nedtonad politisk kritik inom forskningen. Anledningarna till det här ställningstagandet är flera. I enighet med merparten av dagens sociologer och antropologer hävdar jag att studier av nutida sociokulturella fenomen blir både mer etiskt utförda och mer rättvisande när forskare strävar mot ett respektfullt och ömsesidigt utbyte med människorna de undersöker. Personlig kontakt ger inte bara tillgång till mer material utan också större möjlighet för forskarens presentation att utformas under kritisk granskning av dem som är och alltid kommer vara de främsta experterna inom området: de "inomstående".

Huruvida sådan forskning pågår kan diskuteras. De som forskar om Sverigedemokraterna i dag är främst akademiker samt en i sammanhanget ovanligt stor andel journalister och skribenter. Syftet med forskningen 
skiljer sig åt beroende på grupp. Man ser till exempel en tendens bland akademiker att studera partiet utifrån och på avstånd - genom att titta på diverse texter eller valresultat - samt att använda SD som ett exempel utifrån vilket man kan engagera den bredare akademiska diskussionen om politik och främlingsfientlighet i dagens Europa. Journalister och författare använder sig oftare av researchmodeller som liknar etnografi där man skildrar partiet genom kontakt med partimedlemmar.

Borde journalisters studier likställas med de akademiska? Förvisso skulle populära verk förbättras av akademisk granskning, och vissa felinformerade inslag i den offentliga diskussionen angående partiet i dag kommer just från amatörforskare vars arbete aldrig utvärderats av andra experter. Men likväl står de för merparten av befintlig information om personer, organisationer, symbolik och inre politik kring Sverigedemokraterna. Texter av journalister som Stieg Larsson och Mikael Ekman (200I) och Pontus Mattsson (2009) fungerar som referensverk för dagens akademiska forskare. ${ }^{2}$ Dock saknas studier som kombinerar akademisk standard och engagemang inom aktuella diskussioner med utförligt etnografiskt fältarbete. ${ }^{3}$ Det är just sådana studier som behövs för att tydligare klargöra Sverigedemokraternas förhållande till de övriga nationalistiska aktörerna i Sverige.

\section{Ett ideologiskt sammanhang?}

De flesta försök att upptäcka kopplingar mellan partier som SD och mer radikala aktörer i Europa letar efter ideologiska gemensamma nämnare. Anmärkningsvärda studier av detta slag får vi av Mudde (2007) och Harrison och Bruter (20II). ${ }^{4}$ Men den utan tvekan mest kända teorin kommer från historikern Roger Griffin. Han hävdar att många invand-

2. Texter av Niklas Orrenius - både tidningsartiklar och i bokform (t.ex. 20Io) - borde ha samma status.

3. Etnografisk metod används i större utsträckning inom studier av mer radikala utomparlamentariska nationalistiska grupper. Se till exempel Lööw (1998), Fangen (1999), Blee (2002), Gardell (2003) och Simi och Futrell (2010).

4. Jungar och Jupskås (20I4) bjuder på en ovanlig men intressant variation av denna modell när de säger att förutom organisationers ideologi, så kan deras namn fungera som en beskrivande faktor när man identifierar en politisk sammanslutning. 
ringskritiska krafter i Europa förenas i en fascistisk ideologi. Han definierar fascism som en mytisk form av populär ultranationalism fokuserad på drömmen om ett folks återfödelse, så kallad palingenesis (I993, s. 4I). Denna ideologi förutsätter ingen särskild metodik, och därför varierar dess uttrycksform beroende på det politiska sammanhanget. Fascism, enligt Griffin, är ett diakroniskt snarare än ett historiskt fenomen.

En utbredd mottaglighet för kritiska röster mot det moderna samhället under I900-talets första hälft gjorde att fascismen kunde växa till revolutionära, storskaliga och populistiska rörelser, vars tillväxt senare ledde till andra världskriget. Men efter Hitlers och Mussolinis fall behövde ideologin anpassas till en ny politisk verklighet där den liberala demokratin dominerade som politisk modell i väst. Griffin och efterföljande forskare (t.ex. Shekhovtsov 2009, s. 437; Bar-On 2013) ser tre former av fascism i det post-fascistiska Europa: den demokratiska, den revolutionära och den metapolitiska. Demokratiska fascister rörde sig bort från sina föregångares militanta agenda och skapade i stället politiska partier för att locka röster. Medan den demokratiska nyfascistiska formen övergav radikalismen så lämnade den andra nyfascistiska formen - den revolutionära - hoppet om att kultivera en massrörelse. Dessa aktörer, militanta grupper eller gatugäng, behöll sina visioner om en revolution och begränsade sig själva därför till odemokratisk aktivism. Den tredje, metapolitiska formen - inspirerad av den franska nya högern - hävdar att varken demokratiska eller militanta åtgärder kommer kunna påverka samhället inom en överskådlig framtid. Dessa fascister ägnar sig därför åt kulturell och intellektuell verksamhet med avsikt att göra en större publik mer mottaglig för deras idéer.

Den griffinska skolan argumenterar för att viljan att skapa en alternativ modernitet genom nationell återfödelse manifesteras genom demokratisk parlamentarism, våld eller kulturkamp. Denna analys knyter samman diverse aktörer som delar en kärnideologi och skiljer dem sedan åt baserat på deras "politiska stil" (Griffin 2006).

Trots att han säger sig förespråka en "ny konsensus" bland forskare som studerar fascism så har Griffin alltid haft sina kritiker (jfr Gregor 2006; De Grand 2006). De flesta ifrågasätter hans definition av fascism och menar att han saknar grund för sina argument. Kritikerna hävdar 
också att Griffin inkluderar alltför många politiska rörelser i sitt fascismbegrepp. Men hans teori, där en kärnideologi tar sig uttryck på tre olika sätt - demokratiskt, revolutionärt och metapolitiskt - presenterar en lösning där vi kan analysera förhållandet mellan diverse politiska aktörer på högerkanten runt om i Europa.

I Sverige ser vi hur det organiserade invandringsmotståndet, fascistiskt eller inte, följer den här trepartsmodellen: Militanta grupper som Svenska motståndsrörelsen är ett typexempel på den revolutionära inställningen och dess metodik. Den identitära kretsen som verkar på internet genom hemsidor som Motpol.nu, Nordisk.nu och förlaget Arktos, förespråkar en metapolitisk agenda. Och den demokratiska aktivismen? Det har tidigare funnits partier med en liknande ideologi som Svenska motståndsrörelsen, bland andra Nordiska rikspartiet och Nationalsocialistisk front. Men om man vill inkludera Sverigedemokraterna i analysen måste man släppa kravet på ideologisk kontinuitet bland alla parter på kartan.

\section{Etno- och kulturnationalism}

Tvärtemot vad Henrik Arnstads mycket uppmärksammade bok (2013) och tidningsartiklar hävdar kännetecknas inte Sverigedemokraternas ideologi av en vision om "palingenetisk" pånyttfödelse. Hübinette och Lundström (2OII) presenterar en mer korrekt bild av partiets agenda när de beskriver nostalgi i stället för en nostalgi-inspirerad futurism som dess kärna. Tanken att SD skulle ingå i ett fascistiskt sammanhang enligt Griffins teori saknar grund. Dock finns det ideologiska likheter mellan $\mathrm{SD}$, identitärer och rasrevolutionärer. Forskare som Deland, Hertzberg och Hvitfeldt hävdar att dessa aktörer ofta skapar en vi-och-dem-motsättning som ställer "folket" och inhemska minoriteter mot varandra. De flesta skyller på medier och politiker för framväxten av sådana inhemska minoriteter och är negativt inställda till internationella krafter som EU och global kapitalism och progressiva sociala rörelser som feminism (20IO, s. 6-IO).

Men inom denna ideologiska ram finns det vitt åtskilda, till och med totalt oförenliga, ståndpunkter och förslag. Den tydligaste skillnaden ser vi i de olika parternas föreställningar om "folket" och "de Andra". Kate- 
gorierna uppfattas olika beroende på om man förespråkar kultur- eller etnonationalism, det vill säga om man anser att en folkgrupp består av inlärningsbara värderingar och seder eller av biologiskt nedärvda egenskaper. En kulturnationalistisk modell ger minoriteter möjlighet att bli fullvärdiga medborgare genom att ta avstånd från sina traditioner och sin ursprungliga kultur samt anamma nya beteenden och åsikter. Denna möjlighet blir också ett måste i nationalisternas ögon eftersom de vill se en kulturellt homogen befolkning inom nationalstatens gränser. Etnonationalister ser däremot "folket" som en gemenskap man endast kan födas in i, och därför finns ingen plats för utomstående. Försöken att integrera främlingar framstår därför som en hopplös uppgift vars effekt inte blir en ökning av gemenskapens storlek - som kunde vara fallet i kulturnationalistiska sammanhang - utan en urlakning av folkets "essens".

Trots den omfattande mängd litteratur som ifrågasätter och kritiserar kulturnationalismens funktionella avstånd från etnonationalismen (se t.ex. El-Tayeb 20II; Lentin \& Titley 20II; Weber 20I3), och trots möjligheten att kulturnationalism används som en politiskt korrekt fasad för rastänkande, så är skillnaden mellan kultur- och etnonationalism en social verklighet bland invandringsmotståndare i Sverige i dag. Den styr vilken organisation man går med i eller vill associeras med och används ofta som ursäkt för att utestänga oönskade medlemmar. Även om de officiella ställningstagandena inte alltid representerar alla medlemmars åsikter så lockar de folk som ärligt stödjer och vill driva dessa linjer.

Lösningar på frågor om segregation kan avslöja en individs eller grupps egentliga syn på kulturnationalism. Rent teoretiskt ser kulturnationalister segregation som ett problem - ett som lätt kan lösas utan att minoriteter måste utvisas från landet. Deras svar på "ghettoisering" är assimilation. Allt som gör att minoriteter släpper tidigare kulturella tillhörigheter och blandas in i den svenska folkgemenskapen är önskvärt. Etnonationalister å andra sidan ser assimilation inte bara som en omöjlighet, utan också som ett direkt hot mot bevarandet av den biologiska gemenskapen. För dem är segregation en tillfällig lösning - ett sätt att motverka nationalfolkets urlakning på grund av främmande inslag. Det är därför ingen överraskning att vissa etnonationalister förespråkar åtgärder som liknar mångkulturalism - assimilationens motpol - som 
till exempel etableringen av shariazoner i Europa, fortsatt användning av slöja bland Europas muslimska kvinnor, olika etniska skolor, samt en separation av identitet och nationellt medborgarskap. Denna inställning växer snabbt inom den nationalistiska rörelsen i hela Europa och kallas av forskare för heterophilia (Taguieff 200I [1987]), the new racism (Gordon \& Klug 1986; Berbrier 1998; 2000), differential racism (Balibar 2002) och multi-fascism (Fleischer 20I4). ${ }^{5}$

I Sverige är Sverigedemokraterna de främsta förespråkarna av kulturnationalism eller "öppen svenskhet" som de kallar det, ${ }^{6}$ medan nästan alla andra invandringskritiska organisationer är etnonationalistiska. ${ }^{7}$ Sverigedemokraternas position skapar en politik som gör partiets agenda oförenlig med etnonationalistiska krafter. Partiets kulturpolitik, till exempel, har som mål att invandrare i Sverige ska anamma svenska traditioner och värderingar. Vissa partimedlemmar förespråkar en bättre geografisk fördelning av etniska minoriteter i samhället, så att de på sikt lättare kan ta till sig en svensk identitet. ${ }^{8}$ Så länge SD driver sin assimilationspolitik är partiet en fiende för etnonationalister, till och med en större sådan än de krafter som agiterar för att befintliga minoritetsgrupper ska kunna främja och behålla sina kulturella traditioner och skillnader.

Sammanfattningsvis finns det djupa ideologiska och politiska avvikelser mellan Sverigedemokraterna och mer radikala nationalister, där integrationen av invandrare ligger högst på listan. Sett utifrån deras ideo-

5. Grupper associerade med den identitära rörelsen och den franska nya högern har varit de främsta förespråkarna av sådana positioner. Ett exempel på de etnonationalistiskas kritik av assimilation i Sverige får man i denna poddsändning från den identitära tankesmedjan Motpol, publicerad på YouTube I4 mars 20I5: https://www.youtube.com/ watch?v=yuxGc56z2so (hämtat 29 januari 20I6).

6. Med tanke på partiets officiella ställning för kulturnationalism bör forskare undvika att okritiskt använda "etnopluralism" (Rydgren 2002; 2006; Rydgren \& Ruth 20II; Palani 20II) för att beskriva deras ideologi. För mer om begreppets innebörd och historia, se Teitelbaum (2013, s. I03-IO5).

7. Jag är fullt medveten om att det finns en stor ideologisk variation inom den etnonationalistiska sfären, men dess skiljelinjer har inte samma sociala och strategiska konsekvenser som dem jag undersöker här.

8. Dessa policyförslag har tidigare varit kontroversiella inom partiet. Maria Danielsson fick intern kritik efter att hon föreslog att skolelever i Stockholm borde bussas till olika stadsdelar för att motverka segregation. De som var mest kritiska, William Hahne, Gustav Kasselstrand med flera, uteslöts dock ur partiet 2015 på grund av ideologiska avvikelser. 
logiska och politiska agenda borde de ingå i andra allianser än med varandra. Med andra ord, om vi vill förstå vad det är som förenar organiserade motståndare till invandring i Sverige måste vi titta bortom både aktivistiska former och ideologi.

\section{Kulturella kopplingar}

Även om dessa aktörer inte alltid delar grundläggande idéer och strategier så förenas de inom andra områden. Detta gäller i synnerhet när man undersöker kulturella vanor, personliga historier, och social identitet. Då framkommer en gemenskap som sträcker sig över de ideologiska gränserna. Den inkluderar aktiva i den etnonationalistiska sfären samt ett stort antal ledande figurer inom den kulturnationalistiska. Oavsett om de tillhör ett moderat politiskt parti eller en nationalsocialistisk militant grupp så är de flesta yngre eller medelålders män, där merparten har erfarenhet av våldsamma konflikter med vänsteraktivister och antifascister. Sådant förekommer inte bara bland ledande nationalsocialistiska, identitära och autonoma etnonationalistiska figurer som Björn Björkqvist, Magnus Söderman, Daniel Friberg och Vávra Suk (Teitelbaum 20I3), utan också hos ledande sverigedemokrater som Jimmie Åkesson, Erik Almqvist, Björn Söder och Mattias Karlsson (Orrenius 20IO). Alla har de upplevt samma sak: de ideologiska skillnaderna dem emellan återspeglas inte i konflikter med deras motståndare på den politiska vänsterkanten.

Våldsamma sammandrabbningar med den radikala vänstern bidrar till ytterligare ett gemensamt förhållningssätt bland de "inomstående", nämligen att offentligheten är fientligt inställd mot dem och deras agenda. I synnerhet menar de att etablerade medier medvetet framställer dem och deras politik på ett inkorrekt och demoniserande sätt. Därför är det naturligt att många konsumerar varandras mediekanaler. Nättidningar som Avpixlat, Fria Tider, Nya Tider (före detta Nationell idag) till och med nationalsocialistiska Nationell.nu - följs av diverse ideologer och artiklarna delas flitigt via sociala medier. Kontrajihadistiska politiker som Kent Ekeroth sprider artiklar från Nya Tider - en tidning vars redaktion består av både etnonationalister och individer som argumenterat för historierevisionism angående förintelsen under andra världskriget. 
Samtidigt refererar mer nationalsocialistiska röster, som tankesmedjan Motgifts Magnus Söderman, till den SD närstående Avpixlat.

På grund av delade medieplattformar och deltagande i varandras chattforum tar många del av ett insiderspråk. Ord som "ZOG”, ”oikofobi", "batikhäxa" och "metapolitik"9 saknar mening för gemene svensk men är bekanta för de flesta inomstående i invandringskritiska organisationer, även om de inte använder dem själva. Denna samling av inre kulturella yttringar går utöver språket. Som jag skrev i början av den här artikeln känner många till en viss typ av musik, bland annat låtar i vikingarockstil av Ultima Thule samt mer rumsrena låtar av projektet Svensk ungdom. Liksom med ordförrådet är det inte alla som aktivt lyssnar till denna musik, men det faktum att de känner till den tyder på deras ovanliga relation till en subkultur.

I många fall är gemensamma erfarenheter av våld, ett upplevt utanförskap och deltagandet i excentriska kulturyttringar vanliga bland den här gruppen av människor. Många var involverade i I990-talets skinnskallevåg - antingen som direkta deltagare eller genom kompisar. För att återgå till den lista av nyckelpersoner jag nämnde innan, ser vi att Björn Björkqvist, Magnus Söderman, Daniel Friberg, Vávra Suk, Jimmie Åkesson, Erik Almqvist och Mattias Karlsson alla har en bakgrund inom skinnskallekulturen på ett eller annat sätt. ${ }^{\text {Io }}$ När nu samtliga tagit avstånd från denna subkultur, så ser vi att de söker efter en liknande ersättningsidentitet, en baserad på personlig mognad och professionalism (Teitelbaum [kommande]).

Sammanhållningen bland invandringskritiska organisationer i Sverige i dag är inte enbart baserad på ideologi, den beror också på medlemmars kulturella och sociala identitet, vilken har sina rötter i 1990-talets ung-

9. "ZOG" står för "Zionist Occupation Government" och syftar på en variant av föreställningen om en judisk världskonspiration; "oikofobi" syftar, efter den konservative brittiske filosofen Roger Scruton, på en motvilja mot den egna kulturen och de inhemska traditionerna; "batikhäxa" används nedsättande om kvinnor som kritiserar den egna rörelsen; och "metapolitik", som nämnts tidigare, betecknar en opinionsbildningsstrategi inspirerad av den franska nya högern.

IO. I synnerhet var uppdelningen mellan "NS-skins" (nationalsocialistiska) och "Thuleskins" avgörande för de framtida sverigedemokraterna, som ofta hävdar att de enbart umgicks med de senare (Ekman \& Poohl 20I0, s. I50; Teitelbaum 2013, s. 67-72). 
domskultur men ständigt är i förändring. Om vi definierar dessa aktörer utifrån deras kulturella och sociala profil i samband med deras ideologi har vi plötsligt ett analytiskt filter för att bättre isolera olika invandringsmotståndare och mer effektivt särskilja dem från utomstående.

\section{Ett öppet fält}

Fenomenet som jag beskriver här nämns också i dagens forskning. Studier av utomparlamentarisk radikalnationalism fokuserar ofta på organisationers och individers kulturella beteende (Lööw I998; Brown 2004; Miller-Idriss 2009; Simi \& Futrell 20I0), och forskare skriver flitigt om högerpopulistiska "partikulturer". ${ }^{\text {II }}$ Dessutom är förekomsten av kulturella och sociala kopplingar mellan olika nationalistiska grupper välkänd bland kommentatorer. Deland, Hertzberg och Hvitfeldt skriver att trots ideologiska skillnader kan sverigedemokrater och radikalare aktivister vistas i samma chattforum eller på samma konsert med "rasistisk musik" (20Io, s. 6). Ekman och Poohl antyder att kultur och ideologi kan vara separata fenomen inom nationalistiska rörelser när de hävdar att Sverigedemokraternas avståndstagande från nationalsocialister handlar mer om stil än idéer (20I0, s. I49-I50). Vidare arbetar Lodenius med samma förutsättningar när hon skriver att dagens SD är "ett förändrat parti med samma ideologi” (2009, s. 22).

Trots observationer som de ovan existerar det väldigt lite litteratur med fokus på Sverigedemokraternas sociokulturella dimension. Jag ser två anledningar till varför det är så. Den första är att den nuvarande forskningen om SD är politiskt färgad. Ibland visar denna politisering sitt ansikte genom överdrivna påståenden om partiets hot mot den liberala demokratin. Under de senaste åren har vi sett en inflation i analytikers etiketterande och anklagelser mot partiet. Samtidigt har Sverigedemokraternas politiska förändringar gjort att deras ideologiska profil både på papper och i handling blivit mer tvetydig och svårdefinierad. Henrik Arnstads mediasuccé visar att uppmärksamhet och offentligt beröm är givet för den som lyckas höja tonläget mot Sverigedemokraterna.

II. De flesta undersökningar av högerpopulistiska partikulturer behandlar franska Nationella fronten. Ett aktuellt exempel är Shields (2013). 
Vanligtvis handlar dock inte politiseringen om påståenden utan om frågeställningar. Undersökningar som inte berör partiets politiska potential förekommer sällan. Litteraturen domineras i stället av studier som identifierar sociala egenskaper som leder till att väljare stödjer SD (Sannerstedt 2008; Uvell \& Carlsen 20IO; Rydgren \& Ruth 20II), belyser latenta (och alltid problematiska sådana) värderingar och agendor i partiets program (Hellström \& Nilsson 20IO; Norocel 2013; Widfeldt 2015), eller som uttalat vill undersöka och utveckla metoder för att motverka partiets politiska framgång (Thulin 2007; Grönqvist 2008; Hågård 20II; Thorell 20I2; Arneback 20I3). Onekligen behövs sådana studier - särskilt om det kritiska bemötandet av partiet ska ske på forskningsgrund. Men fixeringen vid dessa frågor gör att det mångfacetterade fenomen som Sverigedemokraterna är inte speglas i den akademiska diskursen.

De kulturella, tämligen utomideologiska kopplingarna mellan SD och resten av det nationalistiska Sverige får ytterst lite uppmärksamhet eftersom politisk användning för dem saknas. Bristen på studier som undersöker partiets sociokulturella dimension beror också på att etnografiskt fältarbete, bäst anpassat till sådan forskning, nästan aldrig används i akademiska studier av Sverigedemokraterna. För att få insikt i partimedlemmars vanor, tankar och livsstilar måste forskare gräva djupare än det kvantitativa, djupare än det som förmedlas i formella intervjuer med de berörda. Men återigen, här står fältets politiska profil i vägen. Vill man bevaka en person från nära håll - med tillgång till hens offentliga och privata liv - så måste man samarbeta med personen i någon mening (Lassiter 2005). Chansen för att ett sådant samarbete blir av sjunker markant när projektets syfte är att underminera studieobjektet.

En mindre politiskt engagerad forskning för med sig nya bekymmer. Genom att eliminera kritik kan forskare bidra till normaliseringen av SD. Risken att i stället positivt påverka partiets politiska situation ökar ytterligare när man utvecklar personliga kontakter med partimedlemmar. Sympati och vänskap kan formas i sådana sammanhang, vilket kan leda till att känsliga men relevanta ämnen undviks. Dessa nackdelar är svåra att helt undvika. Men så länge etnografiska studier är en del av en bredare helhet som också inkluderar kritisk forskning får vi en mer livaktig och dynamisk förståelse av Sverigedemokraterna. 


\section{Referenser}

Arneback, Emma 2013. "Bemötanden av främlingsfientlighet i gymnasieskolan”, i Det vita fältet II. Samtida forskning om högerextremism, specialnummer av Arkiv. Tidskrift för sambällsanalys, nr 2, s. 139-165.

DOI: http://dx.doi.org/IO.13068/2000-6217.2.5

Arnstad, Henrik 2013. Älskade fascism. De svartbruna rörelsernas ideologi och historia. Stockholm: Norstedts.

Balibar, Étienne 2002. "Finns det en 'nyrasism'?, i Balibar, Étienne \& Wallerstein, Immanuel, Ras, nation, klass. Mångtydiga identiteter. Göteborg: Daidalos.

Bar-On, Tamir 2013. Rethinking the French New Right. Alternatives to Modernity. London: Routledge.

Berbrier, Mitch 1998. "'Half the Battle': Cultural Resonance, Framing Processes, and Ethnic Affectations in Contemporary White Separatist Rhetoric", Social Problems, 45, 4, s. 43I-45O.

DOI: http://dx.doi.org/10.2307/3097206

Berbrier, Mitch 2000. "The Victim Ideology of White Supremacists and White Separatists in the United States", Sociological Focus, 33, 2, s. I75-191.

DOI: http://dx.doi.org/Io.1080/00380237.2000.10571164

Blee, Kathleen M. 2002. Inside Organized Racism. Women in the Hate Movement. Berkeley: University of California Press.

Brown, Timothy S. 2004. "Subcultures, Pop Music and Politics: Skinheads and 'Nazi Rock' in England and Germany", Journal of Social History, 38, I, s. 157-178. DOI: http://dx.doi.org/I0.1353/jsh.2004.0079

De Grand, Alexander 2006. "Grifin's New Consensus: A Bit Too Minimal?", i Griffin, Roger, Loh, Werner \& Umland, Andreas (red.) Fascism Past and Present, West and East. An International Debate on Concepts and Cases in the Comparative Study of the Extreme Right. Stuttgart: Ibidem-Verlag.

Deland, Mats, Hertzberg, Fredrik \& Hvitfeldt, Thomas 20Io. "Förord”, i Deland, Mats, Hertzberg, Fredrik \& Hvitfeldt, Thomas (red.) Det vita fältet. Samtida forskning om högerextremism. Uppsala: Opuscula historica Upsaliensis 4I. URL: http://urn.kb.se/resolve?urn=urn:nbn:se:uu:diva-I39645

Ekman, Mikael \& Poohl, Daniel 20Io. Ut ur skuggan. En kritisk granskning av Sverigedemokraterna. Stockholm: Natur \& kultur.

El-Tayeb, Fatima 20II. European Others. Queering Ethnicity in Postnational Europe. Minneapolis: University of Minnesota Press.

Fangen, Katrine 1999. "On the Margins of Life: Life Stories of Radical Nationalists", Acta Sociologica, 42, 4, s. 357-373.

DoI: http://dx.doi.org/Io.II77/000I69939904200405

Fleischer, Rasmus 20I4. "Two Fascisms in Contemporary Europe? Understanding the Ideological Split of the Radical Right”, i Deland, Mats, Minkenberg, Michael \& Mays, Christin (red.) In the Tracks of Breivik. Far Right Networks in Northern and Eastern Europe. Berlin: Lit Verlag. 
Gardell, Mattias 2003. Rasrisk. Rasister, separatister och amerikanska kulturkonflikter. 2 utökade utg. Stockholm: Natur \& kultur.

Gordon, Paul \& Klug, Francesca 1986. New Right, New Racism. London: Searchlight Publications.

Gregor, A. James 2006. "Roger Griffin, Social Science, 'Fascism,' and the 'Extreme Right'”, i Griffin, Roger, Loh, Werner \& Umland, Andreas (red.) Fascism Past and Present, West and East. An International Debate on Concepts and Cases in the Comparative Study of the Extreme Right. Stuttgart: Ibidem-Verlag.

Griffin, Roger 1993. The Nature of Fascism. London: Routledge.

Griffin, Roger 2006. "Fascism's New Faces (and Facelessness) in the Post-Fascist Epoch", i Griffin, Roger, Loh, Werner \& Umland, Andreas (red.) Fascism Past and Present, West and East. An International Debate on Concepts and Cases in the Comparative Study of the Extreme Right. Stuttgart: Ibidem-Verlag.

Grönqvist, Björn 2008. Sverigedemokraterna och skolan. En studie av hur Sverigedemokraterna behandlas $i$ samhällskunskapsundervisningen på gymnasiet. Examensarbete på lärarprogrammet. Karlstads universitet.

Harrison, Sarah \& Bruter, Michael 20II. Mapping Extreme Right Ideology. An Empirical Geography of the European Extreme Right. New York: Palgrave Macmillan.

Hellström, Anders \& Nilsson, Tom 2oro. "'We Are the Good Guys'. Ideological Positioning of the Nationalist Party Sverigedemokraterna in Contemporary Swedish Politics", Ethnicities, IO, I, s. 55-76.

DOI: http://dx.doi.org/IO.II77/I4687968093542I4

Hübinette, Tobias \& Lundström, Catrin 20II. "Sweden after the Recent Election: The Double-Binding Power of Swedish Whiteness through the Mourning of the Loss of 'Old Sweden' and the Passing of 'Good Sweden'", NORA - Nordic Journal of Feminist and Gender Research, I9, I, s. 42-52.

DoI: http://dx.doi.org/10.1080/08038740.2010.547835

Hågård, Henrik 20II. Diskutera tills de lärt sig - om lärares syn på värdegrundsarbete och främlingsfientlighet. Examensarbete på lärarprogrammet. Göteborgs universitet.

Jungar, Ann-Cathrine \& Jupskås, Anders Ravik 20I4. "Populist Radical Right Parties in the Nordic Region: A New and Distinct Party Family?", Scandinavian Political Studies, 37, 3, s. 215-238.

DoI: http://dx.doi.org/IO.IIII/I467-9477.12024

Larsson, Stieg \& Ekman, Mikael 200I. Sverigedemokraterna. Den nationella rörelsen. Stockholm: Ordfront/Expo.

Lassiter, Luke Eric 2005. The Chicago Guide to Collaborative Ethnography. Chicago: University of Chicago Press.

Lentin, Alana \& Titley, Gavan 20II. The Crises of Multiculturalism. Racism in the Neoliberal Age. London: Zed Books.

Lodenius, Anna-Lena 2009. "Sverigedemokraternas historia”, i Bengtsson, Håkan A. (red.) Högerpopulismen. En antologi om Sverigedemokraterna. Stockholm: Premiss.

Lodenius, Anna-Lena 20I5. Vi säger vad du tänker. Högerpopulismen i Europa. Stockholm: Atlas. 
Lööw, Heléne 1998. Nazismen i Sverige 1980-1997. Den rasistiska undergroundrörelsen: musiken, myterna, riterna. Stockholm: Ordfront.

Mattsson, Pontus 2009. Sverigedemokraterna in på bara skinnet. Stockholm: Natur \& kultur.

Miller-Idriss, Cynthia 2009. Blood and Culture. Youth, Right-Wing Extremism, and National Belonging in Contemporary Germany. Durham: Duke University Press.

Mudde, Cas 2007. Populist Radical Right Parties in Europe. Cambridge: Cambridge University Press.

Norocel, Ov Cristian 2013. "'Give Us Back Sweden!' A Feminist Reading of the (Re)Interpretations of the Folkhem Conceptual Metaphor in Swedish Radical Right Populist Discourse", NORA - Nordic Journal of Feminist and Gender Research, 2I, I, s. 4-20. DOI: http://dx.doi.org/Io.1080/08038740.2012.741622

Orrenius, Niklas 20Io. Jag är inte rabiat, jag äter pizza. En bok om Sverigedemokraterna. Stockholm: Månpocket.

Palani, Naser 20II. Sverigedemokraterna, frän högerextremister till radikala högerpopulister. Kandidatuppsats. Karlstads universitet.

Rydgren, Jens 2002. "Radical Right Populism in Sweden: Still a Failure, but for How Long?", Scandinavian Political Studies, 25, I, s. 27-56.

DoI: http://dx.doi.org/IO.IIII/I467-9477.00062

Rydgren, Jens 2006. From Tax Populism to Ethnic Nationalism. Radical Right-Wing Populism in Sweden. New York: Berghahn Books.

Rydgren, Jens \& Ruth, Patrick 20II. "Voting for the Radical Right in Swedish Municipalities: Social Marginality and Ethnic Competition?", Scandinavian Political Studies, 34, 3, s. 202-225.

DOI: http://dx.doi.org/IO.IIII/j.I467-9477.20II.00269.x

Sannerstedt, Anders 2008. "De okända väljarna - en analys av de skånska väljare som röstade på icke riksdagspartier 2006", i Nilsson, Lennart \& Antoni, Rudolf (red.) Medborgarna, regionen och flernivådemokratin: Skàne 2006. Göteborg: SOM-institutet.

Shekhovtsov, Anton 2009. "Apoliteic Music: Neo-Folk, Martial Industrial and 'Metapolitical Fascism"', Patterns of Prejudice, 43, 5, s. 43I-457. DOI: http://dx.doi.org/I0.IO80/00313220903338990

Shields, James 20I3. "Marine Le Pen and the 'New' FN: A Change of Style or of Substance?", Parliamentary Affairs, 66, I, s. I79-196. DOI: http://dx.doi.org/IO.IO93/pa/gsso76

Simi, Pete \& Futrell, Robert 20I0. American Swastika. Inside the White Power Movement's Hidden Spaces of Hate. New York: Rowman \& Littlefield.

Taguieff, Pierre-André 200I [1987]. Force of Prejudice. On Racism and its Doubles. Minneapolis: University of Minnesota Press.

Teitelbaum, Benjamin R. 2013. "Come Hear our Merry Song". Shifts in the Sound of Contemporary Swedish Radical Nationalism. Doktorsavhandling. Brown University.

Teitelbaum, Benjamin R. 20I4. "Saga's Sorrow: Femininities of Despair in the Music of Radical White Nationalism." Ethnomusicology, 58, 3, s. 405-430.

Dor: http://dx.doi.org/I0.5406/ethnomusicology.58.3.0405 
Teitelbaum, Benjamin R. 20I6. ”Did Breivik Care about Race? Scandinavian Radical Nationalism in Transition", i Björklund, Jenny \& Lindqvist, Ursula (red.) New Dimensions of Diversity in Nordic Culture and Society. Newcastle: Cambridge Scholars Publishing.

Teitelbaum, Benjamin R. [kommande]. Lions of the North. Sounds of the New Nordic Radical Nationalism. Oxford: Oxford University Press.

Thorell, Richard 2012. Sverigedemokraterna $i$ riksdagen. Vilka konsekvenser fär det för undervisningen? Examensarbete på lärarprogrammet. Karlstads universitet.

Thulin, Marie 2007. Skolvalet och Sverigedemokraterna. Examensarbete på lärarprogrammet. Malmö högskola.

Uvell, Markus \& Carlsen, Erik Meier 20ı.. Folkhemspopulismen. Berättelsen om Sverigedemokraternas väljare. Stockholm: Timbro.

Weber, Beverly M. 2013. Violence and Gender in the "New" Europe. Islam in German Culture. New York: Palgrave Macmillan

Widfeldt, Anders 2015. Extreme Right Parties in Scandinavia. London: Routledge.

Wåg, Mathias 20Io. "Nationell kulturkamp - från vit maktmusik till metapolitik", i Deland, Mats, Hertzberg, Fredrik \& Hvitfeldt, Thomas (red.) Det vita fältet. Samtida forskning om högerextremism. Uppsala: Opuscula historica Upsaliensis 4I. URL: http://urn.kb.se/resolve?urn=urn:nbn:se:uu:diva-I39645 


\section{Tomas Peterson, Mikael Stigendal \& Björn Fryklund}

\section{Skånepartiet}

Om folkligt missnöje i Malmö

Efter 66 års styre förlorade socialdemokratin makten i Malmö vid valet 1985. Den avgörande faktorn därbakom var framgången för Carl P. Herslows Skåneparti. I denna bok ger tre sociologer en ingående skildring av detta partis och dess ledares säregna utveckling. Författarna gör också en djuplodande analys av partiets sympatisörer och deras samhällspolitiska världsbild.

Arkiv förlag 1988, mjukband, 289 sidor

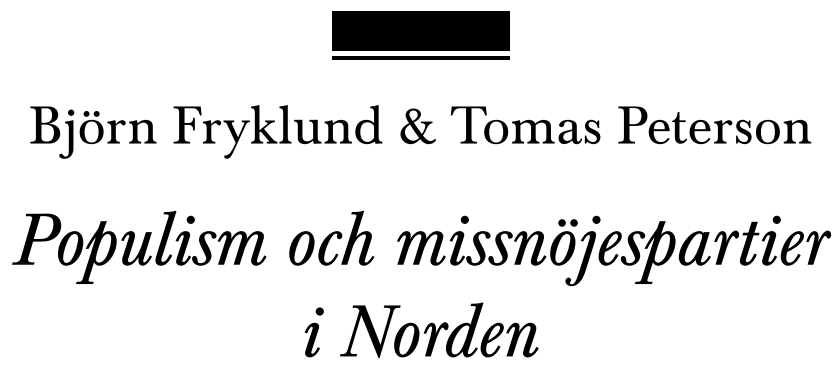

Studier av småborgerlig klassaktivitet

Under de senaste årtiondena har det i de nordiska länderna vuxit fram en ny typ av partier och rörelser, som hämtar sin näring ur ett populistiskt missnöje med det politiska systemet. Mot bakgrund av de fyra nordiska ländernas historia ger författarna en klargörande skildring av dessa rörelsers förutsättningar och betydelse.

Arkiv förlag 1981, mjukband, 470 sidor

»Läs mer om böckerna på www.arkiv.nu« 


\section{Arkiv förlags \\ Moderna klassiker}

Michel Foucault, Vansinnets historia under den klassiska epoken

Claude Lévi-Strauss, Det vilda tänkandet

Jürgen Habermas, Borgerlig offentlighet

Theodor W Adorno, Minima Moralia

Michel Foucault, Övervakning och straff

C Wright Mills, Den sociologiska visionen

Karl Polanyi, Den stora omdaningen

Per Nyström, Historia och biografi. Essäer och artiklar 1933-1989

Robert Brenner, Klasstrider och ekonomisk utveckling under feodalismen

Norbert Elias \& John L Scotson, Etablerade och outsiders

David Riesman, Den ensamma massan

Claude Lévi-Strauss, Spillror av paradiset

Paul Feyerabend, Mot metodtvainget

Raymond Williams, Tv. Teknik och kulturell form

Michel Foucault, Vetandets arkeologi

Eric J Hobsbawm, Massproducerade traditioner

Perry Anderson, Övergångar från antiken till feodalismen

Roland Barthes, Mytologier

Pierre Bourdieu \& Jean-Claude Passeron, Reproduktionen

Albert O Hirschman, Sorti eller protest. En fråga om lojaliteter

Elinor Ostrom, Allmänningen som samhällsinstitution

Marshall Berman, Allt som är fast förflyktigas

Marie Jahoda m.fl., De arbetslösa $i$ Marienthal

Ferdinand de Saussure, Kurs $i$ allmän lingvistik

„Läs mer om böckerna på www.arkivmodernaklassiker.se" 